\title{
Climate Change Combat - A Conspectus
}

\author{
Dar JA',2*, SubashreeK², Bhat NA ${ }^{1}$, Rather $\mathrm{MY}^{2}$, Sundarapandian $\mathrm{SM}^{2}$, Khare $\mathrm{PK}^{1}$ and Khan ML1 \\ ${ }^{1}$ Department of Botany, Dr. HarisinghGour Central University, Sagar, Madhya Pradesh, India \\ ${ }^{2}$ Department of Ecology and Environmental Sciences, Pondicherry University, Puducherry, India
}

Submission: June 27, 2018; Published: July 10, 2018

*Corresponding author: Dar JA,Department of Botany, Dr. HarisinghGour Central University, Sagar, Madhya Pradesh, India,Tel: 7247097405;

Email: javiddar29@gmail.com

\section{Abstract}

Climate change is one of the major issues, which is currently threatening several ecosystems and affecting the livelihoods. Climate change could happen due to natural and/or anthropogenic causes, although the latter has acted as a key trigger in the last few decades. Climate change and global warming are mainly due to the emission of greenhouse gases, of which carbon dioxide is one of the predominant greenhouse gases and several initiatives have been undertaken to reduce its emission and by sequestering it in different carbon pools. Oceans and forests are considered to be important carbon reservoirs in aquatic and terrestrial ecosystems respectively. In forests, carbon is largely stored in vegetation biomass, especially that of trees and soil. Alongside the implementation of carbon mitigation programmes, various databases have also been compiled. However, to effectively combat climate change, it is essential to reach out and spread awareness to the general public and vulnerable sectors, urging them to minimize their individual carbon footprints.

Keywords: Climate Change; Carbon Mitigation; Blue Carbon; Forestry; Carbon Footprint

Abbrevations: UNFCCC: United Nations Framework Convention on Climate Change, $\mathrm{CO}_{2}$ : Carbon Dioxide, ${ }^{\circ} \mathrm{C}$ : Degree Celsius, ppm:Parts Per Million, Pg C:Petagrams of Carbon, REDD: Reduced Emissions from Deforestation and Forest Degradation, REDD+: Reduced Emissions from Deforestation and Forest Degradation Plus, CER: Certified Emission Reduction, EDGAR: The Emissions Database for Global Atmospheric Research

\section{Introduction}

Climate change is an on-going phenomenon, which exerts a profound influence on several ecosystems worldwide, and as a result threatens the livelihoods of people, either, at present or in the near future, especially those from the developing nations that are particularly vulnerable. As defined by United Nations Framework Convention on Climate Change (UNFCCC), climate change is "a change of climate which is attributed directly or indirectly to human activities that alter the composition of the global atmosphere and which are in addition to natural climate variability observed over comparable time periods." In simple words, it could be defined as "any systematic change in the long-term statistics of climatic elements (such as precipitation, temperature, humidity, pressure, winds, etc.) that are sustained over several decades or longer." Climate change could thus be the resultant of natural or anthropogenic triggers, albeit in the recent past, the latter has proven to be a major factor.Climate change and global warming is greatly driven by the emission of greenhouse gases into the atmosphere such as carbon dioxide $\left(\mathrm{CO}_{2}\right)$, methane, nitrous oxide, ozone, hydroflourocarbons, chlorofluorocarbons, etc. It is supposed that the carbon fluxes during the pre-industrial times remained largely in balance, but with the onset of industrial revolution in 1800 [1], the greenhouse gases were emitted in an unprecedentedrates. Thus, the Earth has now entered the Anthropocene epoch [2-4]. Deforestation, fossil fuel combustion, land use change, land degradation $[5,6]$, urbanization, overexploitation of natural resources, etc. are some of the primary anthropogenic causes that have quickened the pace of climate change. The global temperature was $0.71^{\circ} \mathrm{C}$ higher than the $20^{\text {th }}$ century average of $12^{\circ}$ Cas on January 2018 [7]. As warned by UNFCCC, it is estimated that the Earth could warm up anywhere between $1.8^{\circ} \mathrm{C}$ and $4^{\circ} \mathrm{C}$ by 2100 and this increase in global temperature could lead to thermal expansion of the oceans and lead to sea level rise. It has been projected that the sea level rise would be 0.18-0.59 metres by 2100. Besides these, climate change and global warming could significantly alter the type, frequency and intensity of weather events such as cyclones, droughts, floods, etc. and some of these have already been witnessed [8]. Intense heat waves could drastically impact crop production and cause the outbreak of several diseases. These dire consequences of climate change could in turn, disrupt the natural balance further [9].

\section{Carbon Sequestration}

Among the different greenhouse gases, carbon dioxide is an important greenhouse gas, the concentration of which in the atmosphere is on an alarming rise. The concentration of $\mathrm{CO}_{2}$ 
as on May 2018 is 411.31 ppm [7]. Absorbing carbon from the atmosphere and containing the same in different pools on earth is the most effective way of combating climate change, also known as carbon sequestration. Carbon sequestration could be defined as "the process of "transfer and secure storage of atmospheric CO2 in long-lived pools, which would otherwise be emitted or remain in the atmosphere" $[6,10]$. Carbon sequestration takes place in both aquatic and terrestrial ecosystems.

\section{Aquatic Ecosystem}

Of the different aquatic habitats, the oceans play a major role in absorbing and stocking atmospheric $\mathrm{CO}_{2}$, which thus becomes 'blue carbon'. This blue carbon acts as a "buffer to climate change" [11]. The world's oceans are estimated to absorb around 2 billion tonnes of carbon, which would make up for about $25 \%$ of the global annual anthropogenic emissions [12-14]. Besides storing carbon in the biomass of the marine biota such as algae, bacteria, etc., the oceans have an intrinsic capacity to accumulate and store carbon in the sediments for several millennia, without getting saturated $[15,16]$. Carbon sequestration is often one of the primary reasons behind the coastal management and conservation programmes.

\section{Terrestrial Ecosystem}

Carbon sequestration in terrestrial ecosystems has gained widespread attention, especially among researchers, land managers and foresters, who actively look for ways to enhance their carbon mitigation potential. Carbon sequestration occurs in varying capacities in different terrestrial ecosystems, such as agricultural lands, plantations, urban greeneries, natural forests, abandoned lands, etc. However, natural forests are the most efficient carbon absorbers of the different land uses. The global forest carbon accumulation was estimated to be $1.1 \pm 0.8$ Pg C/year [17]. Different forest types have different patterns of carbon sequestration. For example, the tropical forests store $56 \%$ of carbon in their biomass and $32 \%$ in soil, while the boreal forests store only $20 \%$ of carbon in biomass, but $60 \%$ in soil. Overall, the tropical forests store $55 \%$ of world's forest carbon, followed by boreal and temperate forests, which store $32 \%$ and $14 \%$ respectively [17].

It is apparent that the forests store carbon in different pools, each being unique. Principally, there are six different carbon pools - aboveground trees, aboveground non-tree vegetation, belowground roots, forest floor litter, dead wood and soil organic matter [18]. In forests, the atmospheric $\mathrm{CO}_{2}$ is absorbed by plants via photosynthesis and is released back to the atmosphere during respiration. The plant parts, such as wood, roots and the leaf litter return back to the soil and the carbon is again released back to the atmosphere via the processes of respiration and decomposition by heterotrophic organisms [19]. Vegetation biomass and soil are the predominant carbon reservoirs in a forest. In trees, the atmospheric carbon that is fixed by photosynthesis is then transferred to its different organs such as trunk, branches, leaves, reproductive parts, roots, etc. $[20,21]$. The tree trunk, which is rich in lignin is an important compartment of the biomass carbon [22]. Large trees are often regarded as persistent carbon sinks as these keep stocking atmospheric carbon for several decades and even upon death, the rates of decomposition and carbon release are very slow [23]. Soil is a large and dynamic carbon pool that has the potential to store twice the collective amount of carbon stored in the atmosphere and biosphere [24,25].Of the world's soil carbon pool, two-thirds are constituted by the organic carbon, while the rest is held as inorganic carbon [26,27]. Soil organic carbon represents the balance between carbon inputs (from plants) and carbon outputs (by decomposition) and is a continuum of intact plant parts to highly oxidized forms of carbon [28,29]. Soil organic carbon is further categorized into three pools - active pool (labile carbon, comprised of fresh plant and animal parts, which breaks down in a few weeks to few years), passive pool (non-labile carbon, that takes centuries and millennia to get fully decomposed) and slow pool (intermediary stage between the active and passive pools) which have different turnover times [30,31]Recognizing the importance of stocktaking of carbon stored in global forests, several programmes were initiated. The UNFCCC initiated the Reduced Emissions from Deforestation and forest Degradation (REDD) and REDD+ programmes to provide economic incentives to the developing countries that are forestrich, who would enhance the carbon stocks to compensate for the emissions of $\mathrm{CO} 2$ by other nations, that are usually developed [32,33]. A carbon credit, also known as a Certified Emission Reduction (CER) is a permit that allows an organization or a country to emit certain amounts of carbon which could be traded to another organization or country that offsets the emission through forestry or restoration projects. Apart from implementing various carbon mitigation programmes, several datasets on carbon emissions, biomass and carbon stocks have been compiled, such as: BIOMASAR (http://www.biomasar. org/)[34], GEOCARBON Data Portal (https://www.bgcjena. mpg.de/geodb/projects/Home.php)[35], The Emissions Database for Global Atmospheric Research (EDGAR) (http:// edgar.jrc.ec.europa.eu/overview.php?v=CO2andGHG1970 2016\&sort=des9\#)[36], Global Forest Ecosystem Structure and Function Data for Carbon Balance Research (https://daac.ornl. gov/VEGETATION/guides/forest_carbon_flux.html)[37].

\section{Conclusion}

Although climate change is a widely discussed topic in the present days, ways to combat the same have not gained enough outreach yet. Spreading awareness and capacity-building to mitigate and slow down the consequences of climate change is the need of the hour, especially among the vulnerable sections in the developing nations. Also, on an individual level, appropriate eco-friendly measures ought to be taken to minimize the carbon footprints. To conclude, awareness and appropriate steps to enhance carbon sinks and prevent sinks from becoming sources 
could be the important means to effectively combat climate change.

\section{Funding}

The first author is thankful to Science and Engineering Research Board (SERB) for funding under National Post-Doctoral Fellowship Scheme (Ref. No.: PDF/2015/000447).

\section{References}

1. Steffen W, Crutzen PJ, McNeill JR (2007) The Anthropocene: are humans now overwhelming the great forces of nature. AMBIO: A Journal of the Human Environment 36(8): 614-621.

2. Crutzen PJ (2006) The 'Anthropocene' In: Ehlers E, Krafft T (Eds.); Earth System Science in the Anthropocene. Springer, Berlin, Heidelberg, p. 13-18.

3. IPCC (2013) Climate change 2013: the physical science basis In Stocker TF, Qin D, Plattner GK, Tignor M, Allen SK (Eds.); Contribution of Working Group I to the Fifth Assessment Report of the Intergovernmental Panel on Climate Change. Cambridge University Press, Cambridge, pp. 33-118.

4. Monroe JG, Markman DW, Beck WS, Felton AJ, Vahsen ML (2018) Ecoevolutionary Dynamics of Carbon Cycling in the Anthropocene. Trends in Ecology \& Evolution 33(3): 213-225.

5. Denman KL, Brasseur G, Chidthaisong A, Ciais P, Cox PM (2007) Couplings between changes in the climate system and biogeochemistry. In: Solomon SD, Qin M, Manning Z, Chen M, Marquis KB, et al. (eds.) Climate Change 2007: The Physical Science Basis. Contribution of Working Group I to the Fourth Assessment Report of the Intergovernmental Panel on Climate Change. Cambridge University Press. Cambridge, UK and New York, USA.

6. Lorenz K, Lal R (2009) Carbon sequestration in forest ecosystems. Springer Science \& Business Media, Netherlands.

7. NOAA (2018) National Oceanic and Atmospheric Administration.

8. Meehl GA, Stocker TF, Collins WD, Friedlingstein P, Gaye AT (2007) Global Climate Projections. In: Solomon SD, Qin M, Manning Z, Chen M, Marquis KB, et al. (Eds.); Climate Change 2007: The Physical Science Basis. Contribution of Working Group I to the Fourth Assessment Report of the Intergovernmental Panel on Climate Change. Cambridge University Press. Cambridge, UK and New York, USA.

9. United Nations Framework Convention on Climate Change (UNFCCC) Secretariat (2007). Climate Change: Impacts Vulnerabilities and Adaptation in Developing Countries. UNFCCC. Bonn Germany, p. 68.

10. Lal R (2008) Carbon sequestration. Philosophical Transactions of the Royal Society B: Biological Sciences 363(1492): 815-830.

11. Zhang Y, Zhao M, Cui Q Fan W, Qi J (2017) Processes of coastal ecosystem carbon sequestration and approaches for increasing carbon sink. Science China Earth Sciences 60(5): 809-820.

12. Sarmiento JL, Hughes TMC, Stouffer RJ, Manabe S (1998) Simulated response of the ocean carbon cycle to anthropogenic climate warming. Nature 393: 245-249.

13. Sarmiento JL, Wofsy SC (1999) A US Carbon Cycle Science Plan. US Global Change Research Program Washington DC.

14. Canu DM, Ghermandi A, Nunes PA, Lazzari P, Cossarini G (2015) Estimating the value of carbon sequestration ecosystem services in the Mediterranean Sea: An ecological economics approach. Global Environmental Change 32: 87-95.

15. Mcleod E, Chmura GL, Bouillon S, Salm R, Björk M (2011) A blueprint for blue carbon: toward an improved understanding of the role of vegetated coastal habitats in sequestering $\mathrm{CO}_{2}$. Frontiers in Ecology and the Environment 9(10): 552-560.

16. Macreadie PI, Nielsen DA, Kelleway JJ, Atwood TB, Seymour JR (2017) Can we manage coastal ecosystems to sequester more blue carbon? Frontiers in Ecology and the Environment 15(4): 206-213.

17. Pan Y, Birdsey RA, Fang J, Houghton R, Kauppi PE (2011) A large and persistent carbon sink in the world's forests.

18. Pearson T, Walker S, Brown S (2005) Sourcebook for land use land-use change and forestry projects. Winrock International and the BioCarbon Fund of the World Bank p. 57.

19. Ravindranath NH, Ostwald M (2008) Carbon inventory methods: Handbook for greenhouse gas inventory carbon mitigation and roundwood production projects. Springer Science \& Business Media, Springer Netherlands.

20. Aber JD, Melillo JM (2001) Terrestrial ecosystems. Academic San Diego California USA.

21. Körner C (2006) Plant $\mathrm{CO}_{2}$ responses: an issue of definition time and resource supply. New Phytologist 172(3): 393-411.

22. Novaes E, Osorio L, Drost DR, Miles BL, Boaventura-Novaes CR (2009) Quantitative genetic analysis of biomass and wood chemistry of Populus under different nitrogen levels. New Phytologist 182(4): 878890.

23. Lugo AE, Brown S (1992) Tropical forests as sinks of atmospheric carbon. New Phytologist 54(1-4): 239-255.

24. Schlesinger WH (1997) Biogeochemistry an analysis of global change. Academic San Diego California USA.

25. Singh H, Pathak P, Kumar M, Raghubanshi AS (2011) Carbon sequestration potential of Indo-Gangetic agroecosystem soils. Tropical Ecology 52(2): 223-228.

26. Batjes NH (1996) Total carbon and nitrogen in the soils of the world. European Journal of Soil Science 47(2): 151-163.

27. Scharlemann JP, Tanner EV,Hiederer R, Kapos V (2014) Global soil carbon: understanding and managing the largest terrestrial carbon pool. Carbon Management 5(1): 81-91.

28. Schlesinger WH (1977) Carbon balance in terrestrial detritus. Annual Review of Ecology and Systematics 8(1): 51-81.

29. Araujo MA, Zinn YL, Lal R (2017) Soil parent material texture and oxide contents have little effect on soil organic carbon retention in tropical highlands. Geoderma 300: 1-10.

30. Paul EA, Collins HP, Leavitt SW (2001) Dynamics of resistant soil carbon of Midwestern agricultural soils measured by naturally occurring 14C abundance. Geoderma 104(3-4): 239-256.

31. Srivastava P, Singh R, Tripathi S, Singh H, Raghubanshi AS (2016) Soil carbon dynamics and climate change: current agro-environmental perspectives and future dimensions. Energy Ecology and Environment 1(5): 315-322.

32. Kishwan J, Pandey R, Dadhwal VK (2009) India's forest and tree cover: Contribution as a carbon sink. Technical paper 130: 1-12.

33. Sheikh MA, Kumar M, Bussman RW, Todaria NP (2011) Forest carbon stocks and fluxes in physiographic zones of India. Carbon Balance and Management 6(1): 15.

34. BIOMASAR.

35. GEOCARBON Data Portal.

36. The Emissions Database for Global Atmospheric Research EDGAR.

37. Global Forest Ecosystem Structure and Function Data for Carbon Balance Research. 
This work is licensed under Creative Commons Attribution 4.0 License

DOI: 10.19080/IJESNR.2018.13.555857
Your next submission with Juniper Publishers will reach you the below assets

- Quality Editorial service

- Swift Peer Review

- Reprints availability

- E-prints Service

- Manuscript Podcast for convenient understanding

- Global attainment for your research

- Manuscript accessibility in different formats

( Pdf, E-pub, Full Text, Audio)

- Unceasing customer service

Track the below URL for one-step submission https://juniperpublishers.com/online-submission.php 